\title{
IMPLEMENTASI JST PADA PREDIKSI TOTAL LABA RUGI KOMPREHENSIF BANK UMUM KONVENSIONAL DENGAN BACKPROPAGATION
}

\author{
Agus Perdana Windarto', Muhammad Ridwan Lubis², ${ }^{1}$ Solikhun $^{3}$ \\ 1,2,3 AMIK Tunas Bangsa Pematangsiantar \\ Email: ${ }^{1}$ agus.perdana@amiktunasbangsa.ac.id, ${ }^{2}$ m.ridwanlubis@ amiktunasbangsa.ac.id, ${ }^{3}$ solikhun@ \\ amiktunasbangsa.ac.id
}

(Naskah masuk: 12 April 2018, diterima untuk diterbitkan: 05 September 2018)

\begin{abstract}
Abstrak
Total laba rugi komprehensif merupakan hasil yang digunakan untuk mengukur keberhasilan kinerja perusahaan selama periode tertentu yang tidak dipengaruhi oleh operasi normal perusahaan. Informasi total lapa rugi komprehensif sangat penting bagi beberapa pengguna laporan keuangan seperti investor, kreditor dan manajemen dalam memprediksi dimana posisi angka total laba rugi komprehensif untuk menentukan arah investasi masyarakat ke depan, begitu juga bagi pihak bank berguna untuk menentukan kebijakan strategi pemasaran dalam meninggkatkan total laba komprehensif tersebut. Penelitian ini bertujuan untuk membuat prediksi dengan menggunakan Artificial Intelligence dengan algortima backpropagation. Data yang digunakan bersumber dari Otoritas Jasa Keuangan (OJK) pada PT. Bank Mandiri (Persero) Tbk (Januari-Oktober 2016). Untuk melakukan prediksi dengan algortima backpropagation. Proses dilakukan dengan membagi data pelatihan dan pengujian untuk memperoleh model arsitektur terbaik. model arsitektur pelatihan dan pengujian yang digunakan untuk melakukan prediksi Total laba rugi komprehensif yakni: 4-25-1; 4-50-1; 4-50-75-1 dan 4-1001. Dari serangkaian uji coba didapat pola terbaik dari arsitektur backpropagation adalah 4-50-1 dengan Means Square Error 0,0009978666, epoch 1977 dan akurasi 80\% yang selanjutnya akan digunakan untuk melakukan prediksi.
\end{abstract}

Kata kunci: Jaringan saraf tiruan, Back-propagation, Laba Rugi Komprehensif, Prediksi, Ekonomi, Arsitektur

\section{IMPLEMENTATION OF NEURAL NETWORK IN PREDICTING TOTAL COMPREHENSIVE INCOME OF CONVENTIONAL COMMERCIAL BANKS USING BACKPROPAGATION}

\begin{abstract}
Total comprehensive income is the result used to measure the success of a company's performance over a certain period that is not affected by the company's normal operations. Total information on comprehensive loss is very important for some financial report users such as investors, creditors and management in predicting where the position of the total comprehensive income statement is to determine the direction of public investment going forward, as well as for banks to determine marketing strategy in increasing total profit comprehensive. This study aims to make predictions using Artificial Intelligence with backpropagation algorithms. The data used is sourced from the Financial Services Authority (OJK) at PT. Bank Mandiri (Persero) Tbk (January-October 2016). To predict with backpropagation algorithm. The process is carried out by dividing training and testing data to obtain the best architectural model. the training and testing architectural model used to predict the total comprehensive income: 4-25-1; 4-50-1; 4-50-75-1 and 4-100-1. From a series of trials obtained the best pattern of backpropagation architecture is 4-50-1 with Means Square Error 0,0009978666, epoch 1977 and accuracy $80 \%$ which will then be used to make predictions.
\end{abstract}

Keywords: Artificial Neural Network, Back-propagation, Comprehensive Income, Prediction, Economy, Architecture

\section{PENDAHULUAN}

Informasi laporan keuangan merupakan unsur penting bagi investor, kreditor dan pelaku bisnis lainnya. Informasi yang dihasilkan laporan keuangan akan sangat bermanfaat bagi pengguna laporan keuangan apabila informasi tersebut relevan dan bermanfaat untuk pengambilan keputusan. Informasi yang tersaji dalam laporan keuangan pada 
hakekatnya menyajikan keterangan, catatan atau gambaran baik untuk keadaan masa lalu. (Kasmir, 2011) mengatakan bahwa, Laporan keuangan (Medianto \& Almilia, 2014) merupakan catatan mengenai informasi keuangan suatu perusahaan pada suatu periode akuntansi yang dapat digunakan untuk menggambarkan kinerja suatu perusahaan (Riswan \& Kesuma, 2014). Dalam rangka mendorong laju pertumbuhan ekonomi menjadi lebih tinggi, Pemerintah sangat membutuhkan dukungan dari seluruh sektor atau bidang yang dapat menambah income atau pendapatan pemerintah. Jika pengeluaran lebih besar dari pendapatan maka pemerintah akan mengalami defisit dan sulit dalam menjalankan roda kepemerintahan dengan baik. Salah satu pendapat yang penting adalah dari sektor perbankan.

Salah satu instrumen dari keberhasilan suatu perbankan adalah total laba rugi komprehensif (Wahyu \& Praptoyo, 2014). Perbankan harus bisa melakukan prediksi total laba rugi komprehensif kedepan agar pihak bank dapat mengambil langkah atau kebijakan bagaimana membuat strategi-strategi yang handal dalam upaya meningkatkan penghasilan komprehensif ke depan. Begitu juga bagi masyarakat, mereka akan bisa menentukan arah investasi kedepan. Prediksi total laba rugi komprehensif ke depan ditentukan berdasarkan data total laba rugi komprehensif. Berdasarkan data Otoritas Jasa Keuangan (OJK) pada PT. Bank Mandiri (Persero) diperoleh laporan publikasi total laba rugi komprehensif tahun berjalan periode januari s/d november 2016. Berikut data total laba rugi komprehensif tahun berjalan.

Tabel 1. Total Laba Rugi Komprehensif PT. Bank Mandiri,Tbk

\begin{tabular}{lllc}
\hline No & Bulan & \multicolumn{2}{c}{$\begin{array}{c}\text { Total Laba Rugi } \\
\text { Komprehensif }\end{array}$} \\
\hline 1 & Januari & $\mathrm{Rp}$ & 1.351 .543 .000 .000 \\
2 & Februari & $\mathrm{Rp}$ & 3.342 .356 .000 .000 \\
3 & Maret & $\mathrm{Rp}$ & 5.648 .466 .000 .000 \\
4 & April & $\mathrm{Rp}$ & 32.852 .188 .000 .000 \\
5 & Mei & $\mathrm{Rp}$ & 33.438 .427 .000 .000 \\
6 & Juni & $\mathrm{Rp}$ & 33.446 .210 .000 .000 \\
7 & Juli & $\mathrm{Rp}$ & 35.490 .474 .000 .000 \\
8 & Agustus & $\mathrm{Rp}$ & 36.709 .507 .000 .000 \\
9 & September & $\mathrm{Rp}$ & 38.497 .486 .000 .000 \\
10 & Oktober & $\mathrm{Rp}$ & 39.294 .183 .000 .000 \\
11 & November & $\mathrm{Rp}$ & 38.903 .299 .000 .000 \\
\hline & & & $($ sumber: www.ojk.go.id)
\end{tabular}

Dari tabel 1 dapat dijelaskan periode januari total laba rugi komprehensif berada diangka Rp. 1.351.543.000.000, kemudian pada periode februari dan maret mengalami kenaikan sebesar Rp. 1.990.813.000.000 (lebih besar dari periode Januari) dan Rp. 2.306.110.000.000 (lebih besar dari perode februari), pada perode april mengalami kenaikan yang sangat tinggi Rp. 27.203.722.000.000. Periode mei mengalami penurunan Rp. 586.239.000.000, pada periode juni mengalami penurunan kembali pada angka Rp. 7.783.000.000 dan stabil kembali pada periode juli, agustus dan september pada angka Rp. 2.044.264.000.000, Rp. 1.219.033.000.000 dan Rp. 1.787.979.000.000. Mengalami penurunan kembali periode oktober yakni Rp. 796.697.000.000 dan periode november mengalami kerugian pada angka $\mathrm{Rp}-390.884 .000 .000$. Berikut ini tabel total laba rugi komprehensif perbulan dapat dilihat pada tabel 2.

Tabel 2. Keuntungan dan Kerugian Total Laba Rugi Komprehensif PT. Bank Mandiri, Tbk Perbulan

\begin{tabular}{llrr}
\hline No & Bulan & \multicolumn{3}{c}{ Keuntungan dan Kerugian } \\
\hline 1 & Januari & $\mathrm{Rp}$ & 1.351 .543 .000 .000 \\
2 & Februari & $\mathrm{Rp}$ & 1.990 .813 .000 .000 \\
3 & Maret & $\mathrm{Rp}$ & 2.306 .110 .000 .000 \\
4 & April & $\mathrm{Rp}$ & 27.203 .722 .000 .000 \\
5 & Mei & $\mathrm{Rp}$ & 586.239 .000 .000 \\
6 & Juni & $\mathrm{Rp}$ & 7.783 .000 .000 \\
7 & Juli & $\mathrm{Rp}$ & 2.044 .264 .000 .000 \\
8 & Agustus & $\mathrm{Rp}$ & 1.219 .033 .000 .000 \\
9 & September & $\mathrm{Rp}$ & 1.787 .979 .000 .000 \\
10 & Oktober & $\mathrm{Rp}$ & 796.697 .000 .000 \\
11 & November & $\mathrm{Rp}$ & -390.884 .000 .000 \\
\hline \multicolumn{2}{c}{} & \multicolumn{2}{c}{ (sumber: data olahan) }
\end{tabular}

Berdasarkan permasalah diatas, prediksi adalah salah satu solusi yang dapat ditawarkan kepada pengguna informasi investor, kreditor, manajemen dan pihak bank untuk menentukan kebijakan strategi pemasaran dalam meninggkatkan total laba komprehensif tersebut. Salah satu metode problem solving yang digunakan dalam penelitian ini adalah Jaringan Saraf Tiruan (Marleni Anike, Suyoto, \& Ernawati, 2012). Ada banyak teknik yang dapat digunakan untuk implementasi Jaringan Saraf Tiruan yaitu Perceptron, Backpropagation dan Fuzzy (Matondang, 2013). Jaringan Syaraf Tiruan dengan menggunakan algoritma backpropagation telah banyak digunakan untuk menyelesaikan beberapa masalah salah satunya masalah prediksi (WINDARTO, 2017a, 2017b). Di dalam jaringan Backpropagation (Gupta \& Shreevastava, 2011), setiap unit yang berada di lapisan input terhubung dengan setiap unit yang ada di lapisan tersembunyi (Solikhun, Windarto, Handrizal, \& M.Fauzan, 2017). Salah satunya adalah (Sumijan, Windarto, Muhammad, \& Budiharjo, 2016) dengan judul implementation of neural networks in predicting the understanding level of students subject. Penelitian ini menjelaskan bagaimana memprediksi pemahaman mahasiswa terhadapat matakuliah dengan backpropogation. Hasil dari penelitian menunjukkan dari beberapa model arsitektur yang diuji, diperoleh model arsitektur 6-50-1 sebagai model terbaik. Dari model ini diperoleh akurasi mencapai $87,75 \%$. Penelitian berikutnya (Siregar, 2017) dengan judul neural network analysis with backpropogation in predicting Human Development Index (HDI) component by regency/city in north sumatera. Penelitian ini dilakukan untuk meprediksi komponen indeks pembangunan manusia di 
kabupaten sumatera utara dengan backpropogation. Dari 6 pengujian pola arsitektur yaitu: $4-5-1$; 4-10-1; $4-5-10-1 ; \quad 4-10-5-1 ; \quad 4-10-20-1$ dan 4-15-20-1 diperoleh pola arsitektur terbaik adalah 4-10-20-1 dengan epoch 2126, error 0,0011757393, waktu eksekusi 00:16 dan akurasi 100\%.

Berdasarkan alasan tersebut diharapkan hasil penelitian ini dapat membuat prediksi dengan algoritma backpropogation tentang total laba rugi komprehensif yang diharapkan dapat menjadi masukan kepada pihak bank untuk meningkatkan total laba rugi komprehensif tiap bulannnya sehingga masa yang akan datang masyarakat dapat berinvestasi dengan baik sehingga dapat menyokong finansial dan mendorong laju pertumbuhan ekonomi pada sektor perbankan.

\section{METODOLOGI PENELITIAN}

\subsection{Kerangka Kerja Penelitian}

Pada bagian ini kerangka penelitian kerja yang digunakan dalam menyelesaikan masalah penelitian.

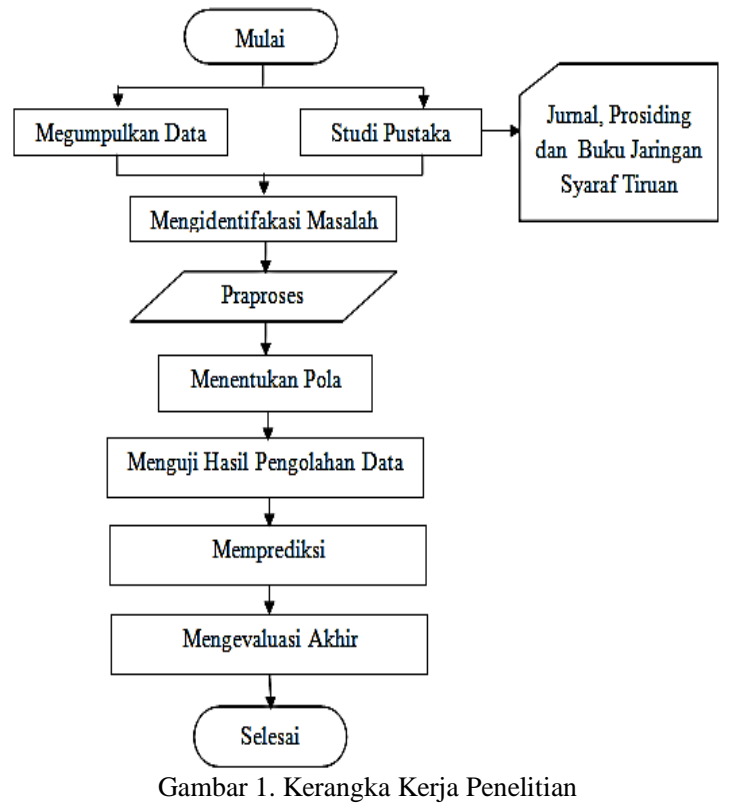

Berdasarkan kerangka kerja pada gambar diatas maka masing-masing langkah dapat diuraikan sebagai berikut :

a) Mengumpulkan Data

b) Studi Pustaka

c) Mengidentifikasi Masalah

d) Praproses

e) Menentukan Model

f) Menguji Hasil Pengolahan Data

g) Memprediksi

h) Mengevaluasi Akhir

\subsection{Jaringan Saraf Tiruan}

Merupakan suatu metode komputasi yang meniru sistem jaringan saraf biologis (Wuryandari \& Afrianto, 2012). Metode ini menggunakan elemen perhitungan non-linier dasar yang disebut neuron yang diorganisasikan sebagai jaringan yang saling berhubungan, sehingga mirip dengan jaringan saraf manusia (Windarto, 2017).

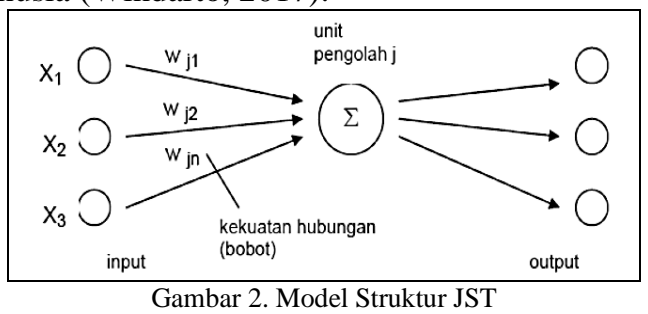

Jaringan saraf tiruan dapat belajar dari pengalaman, melakukan generalisasi atas contoh yang diperolehnya dan mengabstraksi karakteristik esensial masukan bahkan untuk data yang tidak relevan. Algoritma untuk JST beroperasi secara langsung dengan angka sehingga data yang tidak numerik harus diubah menjadi data numerik (Wuryandari \& Afrianto, 2012).

\section{HASIL DAN ANALISA}

\subsection{Penetapan Masukan (Input) dan Keluaran (Output)}

Data total laba rugi komprehensif diolah dengan metode Backpropagation. Agar data dapat dikenali oleh Jaringan Saraf Tiruan, maka data harus direpresentasikan ke bentuk numerik 0-1. Untuk input adalah data total laba rugi komprehensif dan output adalah prediksi total laba rugi komprehensif. Luaran yang dihasilkan mempunyai nilai range 0-1, hal ini dikarenakan jaringan menggunakan fungsi aktivasi sigmoid biner (logsig). Data akan dibagi menjadi 2 bagian, yakni data pelatihan dan data pengujian. Setiap data memiliki input dan output yang berbeda untuk mencari model arsitektur Backpropagation terbaik yang digunakan untuk memprediksi total laba rugi komprehensif untuk periode selanjutnya.

\subsubsection{Penetapan Masukan (Input)}

Variabel total laba rugi komprehensif terdiri dari data total laba rugi komprehensif setiap bulan. Adapun variabel masukan JST tentang total laba rugi komprehensif terdiri dari :

\begin{tabular}{|lll|}
\hline X1 & $=$ & Total Laba Rugi Bulan Januari \\
X2 & $=$ & Total Laba Rugi Bulan Februari \\
X3 & $=$ & Total Laba Rugi Bulan Maret \\
X4 & $=$ & Total Laba Rugi Bulan April \\
X5 & $=$ & Total Laba Rugi Bulan Mei \\
X6 & $=$ & Total Laba Rugi Bulan Juni \\
X7 & $=$ & Total Laba Rugi Bulan Juli \\
X8 & $=$ & Total Laba Rugi Bulan Agustus \\
X9 & $=$ & Total Laba Rugi Bulan September \\
X10 & $=$ & Total Laba Rugi Bulan Oktober \\
\hline
\end{tabular}

\subsubsection{Penetapan Keluaran (Output)}

Adapun penetapan data keluaran adalah data prediksi total laba rugi komprehensif. Adapun variabel keluaran JST adalah Y sebagai prediksi total laba rugi komprehensif. Hasil yang diinginkan pada tahap ini adalah terdeteksinya suatu nilai untuk penentuan pola arsitektur terbaik dari serangkaian penentuan pola yang dilakukan. Kategorisasi pola 
414 Jurnal Teknologi Informasi dan Ilmu Komputer (JTIIK), Vol. 5, No. 4, September 2018, hlm. 411-418

terbaik untuk memprediksi total laba rugi komprehensif adalah dengan menentukan tingkat error minimum dari target total laba rugi komprehensif. Untuk penelitian ini nilai error minimun yang terbaik berkisar diantara 0,09 - 0,001.

\subsection{Pengolahan Data}

Pengolahan data yang dilakukan adalah mengubah data total laba rugi komprehensif perode januari - oktober 2016 dengan cara mentranformasi data tersebut ke range $0-1$ dengan rumus :

$\mathrm{xi}=\frac{0.8(\mathrm{x}-\mathrm{a})}{\mathrm{b}-\mathrm{a}}+0.1$

Dimana

$\mathrm{x}^{1} \quad=$ Hasil konversi data

$\mathrm{x}=$ Nilai yang akan dikonversi

a $\quad=$ Nilai minimum dari suatu data

b = Nilai maksimum dari suatu data

Sebelum data ditranformasi, data input dibagi menjadi 2 bagian, yakni data pelatihan (januari mei) dan data pengujian (juni - oktober) sehingga diperoleh data sebagai berikut :

Tabel 3. Total Laba Rugi Komprehensif 2016 (Dalam Juta) sebagai data pelatihan

\begin{tabular}{lr}
\hline \multicolumn{1}{c}{ Bulan } & $\begin{array}{c}\text { Total Laba Rugi Komprehensif } \\
\text { Komprehensif }\end{array}$ \\
\hline Januari (X1) & Rp1.351.543.000.000 \\
Februari (X2) & Rp1.990.813.000.000 \\
Maret (X3) & Rp2.306.110.000.000 \\
April (X4) & Rp27.203.722.000.000 \\
Mei (Y) & Rp586.239.000.000 \\
\hline
\end{tabular}

Berdasarkan tabel 3, data ini akan dinormalisasi dengan rumus (1) dan membuat pola rotasi dengan input $=4$ dan output $=1$ seperti yang ditunjukkan pada tabel 4 berikut:

Tabel 4. Normalisasi Total Laba Rugi Komprehensif (Dalam Juta) sebagai data pelatihan

\begin{tabular}{cccccc}
\hline \multicolumn{1}{c}{ X1 } & X2 & $\mathbf{X 3}$ & $\mathbf{X 4}$ & Target \\
\hline Pola1 & 0,1230 & 0,1422 & 0,1517 & 0,9000 & 0,1000 \\
Pola2 & 0,1422 & 0,1517 & 0,9000 & 0,1000 & 0,1230 \\
Pola3 & 0,1517 & 0,9000 & 0,1000 & 0,1230 & 0,1422 \\
Pola4 & 0,9000 & 0,1000 & 0,1230 & 0,1422 & 0,1517 \\
Pola5 & 0,1000 & 0,1230 & 0,1422 & 0,1517 & 0,9000 \\
\hline
\end{tabular}

Tabel 5. Total Laba Rugi Komprehensif 2016 (Dalam Juta) sebagai data pengujian

\begin{tabular}{lr}
\hline \multicolumn{1}{c}{ Bulan } & $\begin{array}{r}\text { Total Laba Rugi Komprehensif } \\
\text { Komprehensif }\end{array}$ \\
\hline Juni (X6) & Rp7.783.000.000 \\
Juli (X7) & Rp2.044.264.000.000 \\
Agustus (X8) & Rp1.219.033.000.000 \\
September (X9) & Rp1.787.979.000.000 \\
Oktober (y) & Rp796.697.000.000 \\
\hline
\end{tabular}

Berdasarkan tabel 5, data ini akan dinormalisasi dengan rumus (1) dan membuat pola rotasi dengan input $=4$ dan output $=1$ seperti yang ditunjukkan pada tabel 6 berikut:

Tabel 6. Normalisasi Total Laba Rugi Komprehensif (Dalam Juta) sebagai data pengujian

\begin{tabular}{lccccc}
\hline & X1 & X2 & X3 & X4 & Target \\
\hline Pola6 & 0,1000 & 0,9000 & 0,5758 & 0,7993 & 0,4099 \\
Pola7 & 0,9000 & 0,5758 & 0,7993 & 0,4099 & 0,1000 \\
Pola8 & 0,5758 & 0,7993 & 0,4099 & 0,1000 & 0,9000 \\
Pola9 & 0,7993 & 0,4099 & 0,1000 & 0,9000 & 0,5758 \\
Pola10 & 0,4099 & 0,1000 & 0,9000 & 0,5758 & 0,7993 \\
\hline
\end{tabular}

Berdasarkan tabel 4 dan 6 , normalisasi data total laba rugi komprehensif terdiri dari 10 pola yang dirotasikan. Pola ini dibagi menjadi 2 bagian. Data pelatihan (traning) terdiri dari pola $1 \mathrm{~s} / \mathrm{d} 5$. Data pengujian (testing) terdiri dari pola $6 \mathrm{~s} / \mathrm{d} 10$. Model arsitektur yang digunakan adalah 4-25-1; 4-50-1; 450-75-1 dan 4-100-1 dengan menggunakan tools Matlab dengan parameter:

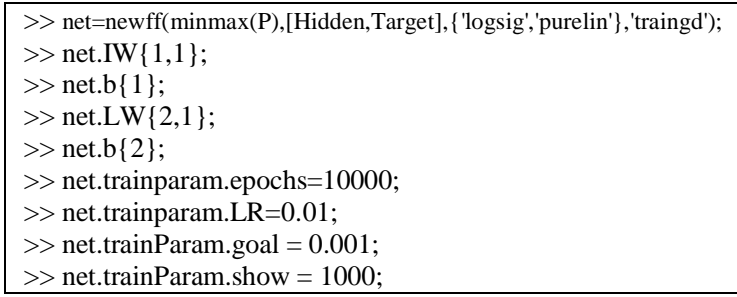

\subsection{Arsitektur Pelatihan dan Pengujian 4-25-1}

Berikut ini hasil pelatihan arsitektur 4-25-1 dengan tools matlab bahwa Epoch training $=3108$ dan Mean Square Error (MSE) sebesar 0,0009994342.

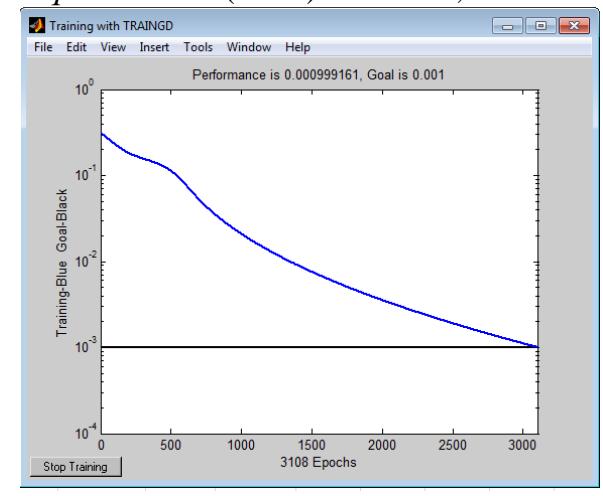

Gambar 4. Hasil Epoch Training Dengan Arsitektur 4-25-1

Berikut ini hasil data pelatihan dan pengujian untuk arsitektur 4-25-1 seperti pada tabel 7 dan 8 berikut

\begin{tabular}{|c|c|c|c|c|c|}
\hline \multirow{2}{*}{ No } & \multirow{2}{*}{ Real } & \multirow{2}{*}{ Target } & \multicolumn{3}{|c|}{ ANN 4-25-1 } \\
\hline & & & Output & Error & SSE \\
\hline 1 & Pola 1 & 0,1000 & 0,1242 & $-0,024$ & 0,0005856400 \\
\hline 2 & Pola 2 & 0,1230 & 0,1563 & $-0,033$ & 0,0011087872 \\
\hline 3 & Pola 3 & 0,1422 & 0,1639 & $-0,022$ & 0,0004702357 \\
\hline 4 & Pola 4 & 0,1517 & 0,1598 & $-0,008$ & 0,0000657483 \\
\hline \multirow[t]{2}{*}{5} & Pola 5 & 0,9000 & 0,8474 & 0,053 & 0,0027667600 \\
\hline & & & & $\begin{array}{l}\text { Total } \\
\text { MSE }\end{array}$ & $\begin{array}{l}0,0049971712 \\
0,0009994342\end{array}$ \\
\hline
\end{tabular}

\begin{tabular}{|c|c|c|c|c|c|c|}
\hline \multirow{2}{*}{ No } & \multirow{2}{*}{ Real } & \multirow{2}{*}{ Target } & \multicolumn{4}{|c|}{ ANN 4-25-1 } \\
\hline & & & Output & Error & SSE & Hasil \\
\hline 1 & Pola 6 & 0,4099 & 0,0030 & 0,407 & 0,1655778954 & Salah \\
\hline 2 & Pola 7 & 0,1000 & 0,0951 & 0,005 & 0,0000240100 & Benat \\
\hline 3 & Pola 8 & 0,9000 & 0,2871 & 0,613 & 0,3756464100 & Salah \\
\hline 4 & Pola 9 & 0,5758 & 0,0290 & 0,547 & 0,2990129773 & Salah \\
\hline \multirow[t]{2}{*}{5} & Pola 10 & 0,7993 & 0,1535 & 0,646 & 0,4170865847 & Salah \\
\hline & & & & Total & $\begin{array}{l}1,2573478774 \\
0.2514695755\end{array}$ & $20 \%$ \\
\hline
\end{tabular}


Berdasarkan tabel 8, tingkat akurasi kebenaran $20 \%$

\subsection{Arsitektur Pelatihan dan Pengujian 4-50-1}

Berikut ini hasil pelatihan arsitektur 4-50-1 dengan tools matlab bahwa Epoch training $=1977$ dan Mean Square Error (MSE) sebesar 0,000997867.

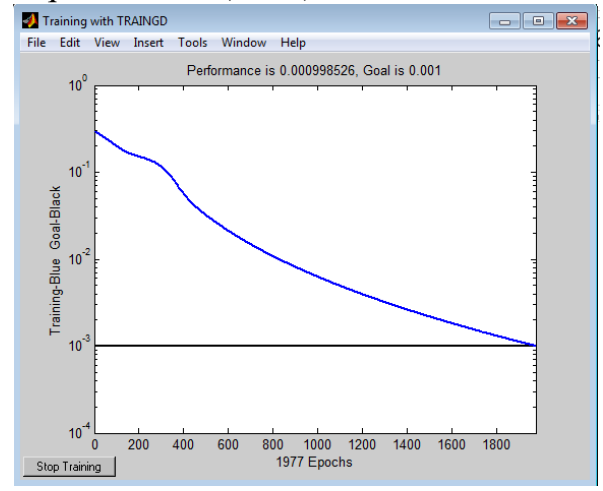

Gambar 5. Hasil Epoch Training Dengan Arsitektur 4-50-1

Berikut ini hasil data pelatihan dan pengujian untuk arsitektur 4-50-1 seperti pada tabel 9 dan 10 berikut

\begin{tabular}{cccccc}
\multicolumn{2}{l}{ Tabel 9. Pelatihan arsitektur 4-50-1 } \\
\hline \multirow{2}{*}{ No } & \multirow{2}{*}{ Real } & \multirow{2}{*}{ Target } & \multicolumn{3}{c}{ ANN 4-50-1 } \\
\cline { 4 - 6 } & & Output & Error & SSE \\
\hline 1 & Pola 1 & 0,1000 & 0,1079 & $-0,008$ & 0,0000624100 \\
2 & Pola 2 & 0,1230 & 0,1583 & $-0,035$ & 0,0012459810 \\
3 & Pola 3 & 0,1422 & 0,1664 & $-0,024$ & 0,0005849103 \\
4 & Pola 4 & 0,1517 & 0,1647 & $-0,013$ & 0,0001692219 \\
5 & Pola 5 & 0,9000 & 0,8459 & 0,054 & 0,0029268100 \\
\hline & & & 3 & Total & 0,0049893332 \\
& & & & MSE & 0,0009978666 \\
\hline
\end{tabular}

$\underline{\text { Tabel 10. Pengujian arsitektur 4-50-1 }}$

\begin{tabular}{ccccccc}
\hline \multirow{2}{*}{ No } & \multirow{2}{*}{ Real } & \multirow{2}{*}{ Target } & \multicolumn{4}{c}{ ANN 4-50-1 } \\
\cline { 4 - 7 } & & Output & Error & SSE & Hasil \\
\hline 1 & Pola 6 & 0,4099 & 0,5073 & $-0,097$ & 0,0094842982 & Benar \\
2 & Pola 7 & 0,1000 & 0,1035 & $-0,003$ & 0,0000122500 & Benar \\
3 & Pola 8 & 0,9000 & 0,0781 & 0,822 & 0,6755196100 & Salah \\
4 & Pola 9 & 0,5758 & 0,5802 & $-0,004$ & 0,0000191775 & Benar \\
5 & Pola 10 & 0,7993 & 0,7825 & 0,017 & 0,0002829935 & Benar \\
\hline & & & & Total & 0,6853183291 & $\mathbf{8 0}$ \\
\hline
\end{tabular}

Berdasarkan tabel 10, tingkat akurasi kebenaran $80 \%$

\subsection{Arsitektur Pelatihan dan Pengujian 4-50-75-}

Berikut ini hasil pelatihan arsitektur 4-50-75-1 dengan tools matlab bahwa Epoch training $=538$ dan Mean Square Error sebesar 0,000998121454.

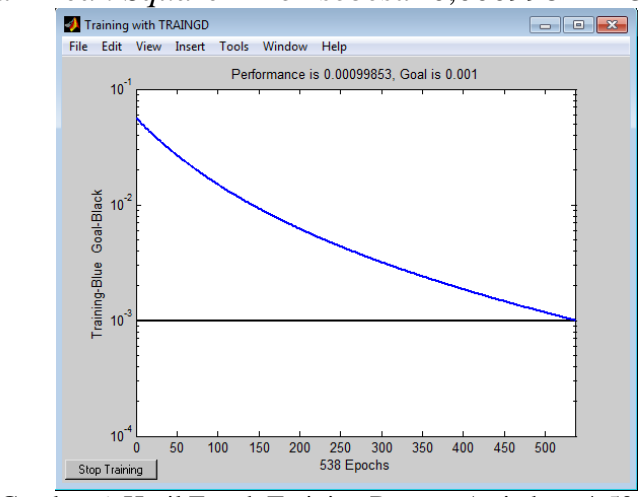

Gambar 6. Hasil Epoch Training Dengan Arsitektur 4-50-75-1
Berikut ini hasil data pelatihan dan pengujian untuk arsitektur 4-50-75-1 seperti pada tabel 11 dan 12 berikut

Tabel 11. Pelatihan arsitektur 4-50-75-1

\begin{tabular}{cccccc}
\hline \multirow{2}{*}{ No } & \multirow{2}{*}{ Real } & \multirow{2}{*}{ Target } & \multicolumn{3}{c}{ ANN 4-50-75-1 } \\
\cline { 4 - 6 } & & Output & Error & \multicolumn{1}{c}{ SSE } \\
\hline 1 & Pola 1 & 0,1000 & 0,1052 & $-0,005$ & 0,0000270400 \\
2 & Pola 2 & 0,1230 & 0,1578 & $-0,035$ & $0,00121 \mathrm{i} 09326$ \\
3 & Pola 3 & 0,1422 & 0,1612 & $-0,019$ & 0,0003604272 \\
4 & Pola 4 & 0,1517 & 0,1580 & $-0,006$ & 0,0000397976 \\
5 & Pola 5 & 0,9000 & 0,8421 & 0,058 & 0,0033524100 \\
\hline & & & & Total & 0,0049906073 \\
& & & & MSE & 0,0009981215 \\
\hline
\end{tabular}

Tabel 12. Pengujian arsitektur 4-50-75-1

\begin{tabular}{ccccccc}
\hline \multirow{2}{*}{ No } & \multirow{2}{*}{ Real } & \multirow{2}{*}{ Target } & \multicolumn{4}{c}{ ANN 4-50-75-1 } \\
\cline { 4 - 7 } & & Output & Error & SSE & Hasil \\
\hline 1 & Pola 6 & 0,4099 & 0,7667 & $-0,357$ & 0,1272972213 & Salah \\
2 & Pola 7 & 0,1000 & 0,0567 & 0,043 & 0,0018748900 & Benar \\
3 & Pola 8 & 0,9000 & 0,1530 & 0,747 & 0,5580090000 & Salah \\
4 & Pola 9 & 0,5758 & 0,0794 & 0,496 & 0,2464336016 & Salah \\
5 & Pola 10 & 0,7993 & 0,0178 & 0,782 & 0,6107772767 & Salah \\
\hline & & & & Total & 1,5443919896 & $\mathbf{2 0}$ \\
\hline
\end{tabular}

Berdasarkan tabel 12, tingkat akurasi kebenaran $20 \%$

\subsection{Arsitektur Pelatihan dan Pengujian 4-100-1}

Berikut ini hasil pelatihan arsitektur 4-100-1 dengan tools matlab bahwa Epoch training $=5347$ dan Mean Square Error sebesar 0,000998725737.

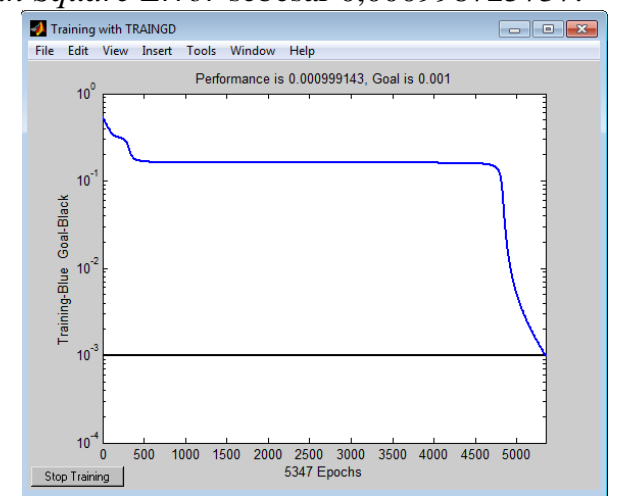

Gambar 7. Hasil Epoch Training Dengan Arsitektur 4-100-1

Berikut ini hasil data pelatihan dan pengujian untuk arsitektur 4-100-1 seperti pada tabel 13 dan 14 berikut

Tabel 13. Pelatihan arsitektur 4-100-1

\begin{tabular}{cccccc}
\hline \multirow{2}{*}{ No } & \multirow{2}{*}{ Real } & \multirow{2}{*}{ Target } & \multicolumn{3}{c}{ ANN 4-100-1 } \\
\cline { 4 - 6 } & & Output & Error & SSE \\
\hline 1 & Pola 1 & 0,1000 & 0,1353 & $-0,035$ & 0,0012460900 \\
2 & Pola 2 & 0,1230 & 0,1414 & $-0,018$ & 0,0003385032 \\
3 & Pola 3 & 0,1422 & 0,1602 & $-0,018$ & 0,0003234573 \\
4 & Pola 4 & 0,1517 & 0,1680 & $-0,016$ & 0,0002659682 \\
5 & Pola 5 & 0,9000 & 0,8469 & 0,053 & 0,0028196100 \\
\hline & & & & Total & 0,0049936287 \\
& & & & MSE & 0,0009987257 \\
\hline
\end{tabular}

Tabel 14. Pengujian arsitektur 4-100-1

\begin{tabular}{ccccccc}
\hline \multirow{2}{*}{ No } & \multirow{2}{*}{ Real } & \multirow{2}{*}{ Target } & \multicolumn{4}{c}{ ANN 4-100-1 } \\
\cline { 4 - 7 } & & Output & Error & SSE & Hasil \\
\hline 1 & Pola 6 & 0,4099 & 0,0012 & 0,409 & 0,1670460209 & Salah \\
2 & Pola 7 & 0,1000 & 0,1295 & $-0,030$ & 0,0008702500 & Benar \\
3 & Pola 8 & 0,9000 & 0,1592 & 0,741 & 0,5487846400 & Salah \\
4 & Pola 9 & 0,5758 & 0,0038 & 0,572 & 0,3272077852 & Salah \\
5 & Pola 10 & 0,7993 & 0,131 & 0,668 & 0,4466548432 & Salah \\
\hline & & & & Total & 1,4905635392 & 20 \\
& & & & MSE & 0,2981127078 & \\
\hline
\end{tabular}


Berdasarkan tabel 14, tingkat akurasi kebenaran $20 \%$

\subsection{Pemilihan Model Arsitektur Terbaik}

Berdasarkan hasil pelatihan dan pengujian dengan menggunakan 4 model arsitektur pada algoritma backpropogation yakni: 4-25-1; 4-50-1; 4-50-75-1 dan 4-100-1, diperoleh model arsitektur 4-50-1 adalah yang terbaik dengan hasil akurasi prediksi $80 \%$. Berikut ini hasil lengkap dari 4 model yang digunakan seperti yang ditunjukkan pada tabel 15

\begin{tabular}{|c|c|c|c|c|}
\hline & $4-25-1$ & $4-50-1$ & $\begin{array}{l}4-50-75-1 \\
\end{array}$ & 4-100-1 \\
\hline MSE & 0,0009994342 & 0,0009978666 & 0,0009981215 & 0,0009987257 \\
\hline Epoch & 3108 & 1977 & 538 & 5347 \\
\hline Akurasi & $20 \%$ & $80 \%$ & $20 \%$ & $20 \%$ \\
\hline
\end{tabular}

\subsection{Prediksi Total Laba Rugi Komprehensif}

Dari hasil perancangan yang dibuat dihasilkan model terbaik untuk arsitektur 4-50-1. Model ini akan digunakan untuk memprediksi total laba rugi komprehensif dengan menentukan $\mathrm{Y}$ aktual dan Y prediksi dari Backpropagation. Adapun rumus yang digunakan untuk memprediksi total laba rugi komprehensif adalah model arsitektur 4-100-1 adalah :

$\left.\mathrm{x}=\left(\left(\mathrm{x}^{\prime}-0,1\right)(\mathrm{x} \cdot \max -\mathrm{xmin}) / 0,8\right)\right)+\mathrm{x} \cdot \min$

Keterangan :

$$
\begin{array}{ll}
x, & =\text { Data Normalisasi } \\
x . \max & =\text { Data Maksimal Asli } \\
x . \min & =\text { Data Minimal Asli }
\end{array}
$$

Berikut ini hasil prediksi dengan menggunakan model arsitektur terbaik seperti yang ditunjukkan

\begin{tabular}{|c|c|c|c|c|c|c|c|c|}
\hline No & Bulan & Tahun & Total Laba Rugi Komprehensif & $\begin{array}{c}\text { Normalisasi } \\
\text { (Y aktual) }\end{array}$ & $\begin{array}{l}\text { Prediksi Total } \\
\text { Laba Rugi } \\
\text { Komprehensif }\end{array}$ & $\begin{array}{c}Y \\
\text { Prediksi }\end{array}$ & $E$ & $e 2$ \\
\hline 1 & Juli & & Rp2.044.264 & 0,8223 & Rp2.017.532 & 0,8144 & 0,0079 & 0,0000624100 \\
\hline 2 & Agustus & & Rp1.219.033 & 0,5775 & Rp1.186.520 & 0,5679 & 0,0096 & 0,0000921600 \\
\hline 3 & September & 2016 & Rp1.787.979 & 0,7463 & Rp1.766.711 & 0,7400 & 0,0063 & 0,0000396900 \\
\hline 4 & Oktober & & Rp796.697 & 0,4523 & Rp799.839 & 0,4532 & $-0,0009$ & 0,0000008100 \\
\hline \multirow[t]{2}{*}{5} & November & & $(\mathrm{Rp} 390.884)$ & 0,1000 & (Rp313.008) & 0,1231 & $-0,0231$ & 0,0005336100 \\
\hline & & & & & & & $\begin{array}{l}\text { MSE } \\
\text { Akurasi }\end{array}$ & $\begin{array}{l}\mathbf{0 , 0 0 0 1 4 5 7 3 6 0} \\
80 \%\end{array}$ \\
\hline
\end{tabular}
pada tabel berikut:

Tabel 16. Hasil Prediksi Total Laba Rugi Komprehensif dengan Model 4-50-1 (Dalam Juta)

\section{KESIMPULAN DAN SARAN}

Berdasarkan hasil dan pembahasan diatas, maka penulis dapat mengambil kesimpulan sebagai berikut:

1. Menambahkan banyak hidden layer pada saat pelatihan dan pengujian, bukan merupakan suatu hasil yang maksimal. Untuk 4 model arsitektur yang dirancang, 4-50-75-1 adalah model yang memiliki tingkat MSE terbesar yaitu 0,3088783979 dan epoch tercepat yakni 538, tetapi memiliki tingkat akurasi kebenaran $20 \%$.

2. Setelah dilakukan percobaan dalam proses pelatihan dan pengujian sistem dengan menggunakan software Matlab 6.1, Model arsitektur 4-50-1 adalah yang terbaik hasil dengan Epoch training $=1977$ dan Mean Square Error (MSE) sebesar 0,000997867

3. Dengan model arsitektur 4-50-1, prediksi total laba rugi komprehensif menunjukkan akurasi $80 \%$.

\section{UCAPAN TERIMA KASIH}

Ucapan terima kasih kami sampaikan kepada Direktorat Riset dan Pengabdian Masyarakat Direktorat Jenderal Penguatan Riset dan Pengembangan Kementerian Riset, Teknologi dan Pendidikan Tinggi atas pendanaan Penelitian Dosen Pemula (PDP) tahun pelaksanaan 2018

\section{DAFTAR PUSTAKA}

GUPTA, A., \& SHREEVASTAVA, M. (2011).
Medical Diagnosis using Back propagation Algorithm. International Journal of Emerging Technology and Advanced Engineering, 1(1), 55-58.

KASMIR. (2011). Analisis Laporan Keuangan. Jakarta: Raja Grafindo Persada.

MARLENI ANIKE, SUYOTO, \& ERNAWATI. (2012). Pengembangan Sistem Jaringan Syaraf Tiruan Dalam Memprediksi Jumlah Dokter Keluarga Menggunakan Backpropagation (Studi Kasus: Regional X Cabang Palu). Seminar Nasional Teknologi Informasi Dan Komunikasi 2012 (SENTIKA 2012), 209-216.

MATONDANG, Z. A. (2013). Jaringan Syaraf Tiruan Dengan Algoritma Backpropagation Untuk Penentuan Kelulusan Sidang Skripsi. Pelita Informatika Budi Darma, IV(1), 84-93.

MEDIANTO, A. A., \& ALMILIA, L. S. (2014). Dampak laba rugi komprehensif, terhadap kinerja keuangan, ukuran perusahaan dan risiko perusahaan. Eprint Perbanas, 1-13.

RISWAN, \& KESUMA, Y. F. (2014). Analisis Laporan Keuangan Sebagai Dasar Dalam Penilaian Kinerja Keuangan PT. Budi Satria Wahana Motor. Jurnal Akuntansi \& Keuangan, 5(1), 93-121. Retrieved from https://media.neliti.com

SIREGAR, M. N. H. (2017). Neural Network Analysis With Backpropogation In Predicting Human Development Index ( HDI ) Component by Regency/City In North Sumatera. IJISTECH, 1(1), 22-33. 
SOLIKHUN, WINDARTO, A. P., HANDRIZAL, \& M.FAUZAN. (2017). Jaringan Saraf Tiruan Dalam Memprediksi Sukuk Negara Ritel Berdasarkan Kelompok Profesi Dengan Backpropogation Dalam Mendorong Laju Pertumbuhan Ekonomi. Kumpulan jurnaL Ilmu Komputer (KLIK), 4(2), 184-197.

SUMIJAN, WINDARTO, A. P., MUHAMMAD, A., \& BUDIHARJO. (2016). Implementation of Neural Networks in Predicting the Understanding Level of Students Subject. International Journal of Software Engineering and Its Applications, 10(10), 189-204. Retrieved from http://dx.doi.org/10.14257/ijseia.2016.10.10.1 8

WAHYU, R. P. S., \& PRAPTOYO, S. (2014). Penyajian dan komponen other comprehensive income. Jurnal Ilmu \& Riset Akuntansi, 3(12), 2014.

WINDARTO, A. P. (2017). Implementation of Data Mining on Rice Imports by Major Country of Origin Using Algorithm Using K-Means
Clustering Method. International Journal of Artificial Intelligence Research, 1(2), 26-33. Retrieved from http://ijair.id/index.php/ijair/article/view/17

WINDARTO, A. P. (2017a). Implementasi Jst Dalam Menentukan Kelayakan Nasabah Pinjaman KUR Pada Bank Mandiri Mikro Serbelawan Dengan Metode Backpropogation. J-SAKTI (Jurnal Sains Komputer Dan Informatika), 1(1), 12-23.

WINDARTO, A. P. (2017b). Implementasi metode topsis dan saw dalam memberikan reward pelanggan. Kumpulan jurnaL Ilmu Komputer (KLIK), 4(1), 88-101. Retrieved from http://klik.unlam.ac.id/index.php/klik/article/vi ew/73

WURYANDARI, \& AFRIANTO. (2012). Perbandingan Metode Jaringan Syaraf Tiruan Backpropogation dengan Learning Vector Quantization pada pengenalan wajah. Jurnal KOMPUTA, 11(1), 2012. 
Halaman ini sengaja dikosongkan 